\title{
Novel agents for anti-platelet therapy
}

\author{
Xuebin Ji and Ming Hou
}

\begin{abstract}
Anti-platelet therapy plays an important role in the treatment of patients with thrombotic diseases. The most commonly used anti-platelet drugs, namely, aspirin, ticlopidine, and clopidogrel, are effective in the prevention and treatment of cardio-cerebrovascular diseases. Glycoprotein Ilb/Illa antagonists (e.g., abciximab, eptifibatide and tirofiban) have demonstrated good clinical benefits and safety profiles in decreasing ischemic events in acute coronary syndrome. However, adverse events related to thrombosis or bleeding have been reported in cases of therapy with glycoprotein $\mathrm{Ilb} / \mathrm{llla}$ antagonists. Cilostazol is an anti-platelet agent used in the treatment of patients with peripheral ischemia, such as intermittent claudication. Presently, platelet adenosine diphosphate P2Y(12) receptor antagonists (e.g., clopidogrel, prasugrel, cangrelor, and ticagrelor) are being used in clinical settings for their pronounced protective effects. The new protease-activated receptor antagonists, vorapaxar and atopaxar, potentially decrease the risk of ischemic events without significantly increasing the rate of bleeding. Some other new anti-platelet drugs undergoing clinical trials have also been introduced. Indeed, the number of new antiplatelet drugs is increasing. Consequently, the efficacy of these anti-platelet agents in actual patients warrants scrutiny, especially in terms of the hemorrhagic risks. Hopefully, new selective platelet inhibitors with high antithrombotic efficiencies and low hemorrhagic side effects can be developed.
\end{abstract}

Keywords: anti-platelet, agent, therapy, antagonist, thrombotic disease

\section{Introduction}

Thrombotic diseases and their complications may have severe consequences. Platelets play a key role in thrombosis, and anti-platelet therapies may prevent as well as treat thrombotic diseases. Therefore, anti-platelet drugs that can inhibit platelet adhesion, aggregation, release, and activation need to be developed (Figure 1). The most commonly used anti-platelet drugs, namely, aspirin, clopidogrel, and ticlopidine are effective in preventing thrombotic diseases. With the developments in medicine and pharmacy, the number of anti-platelet agents is continuously increasing.

\section{Platelet glycoprotein (GP) IIb/Illa receptor antagonists (Table 1)}

The adhesion, aggregation, release, and activation of platelets can induce platelet thrombosis, which is important in physiological hemostasis and pathological thrombosis. Once platelets are activated, GP IIb/IIIa receptors on the surfaces of platelets transform into their active

\footnotetext{
* Correspondence: houming@medmail.com.cn

* Correspondence: houming@medmail.com.cn
Department of Hematology, Qilu Hospital of Shandong University, Jinan, China PR
}

(c) $2011 \mathrm{Ji}$ and Hou; licensee BioMed Central Ltd. This is an Open Access article distributed under the terms of the Creative Commons Attribution License (http://creativecommons.org/licenses/by/2.0), which permits unrestricted use, distribution, and reproduction in any medium, provided the original work is properly cited. Willebrand factor (vWF). The GP IIb/IIIa receptor operates in the final common pathway of platelet aggregation. Blocking the GP IIb/IIIa receptor can inhibit platelet aggregation induced by activating factors. Once platelet aggregation is inhibited, platelet thrombi cannot form.

The development of GP IIb/IIIa antagonists, such as the recently approved abciximab, eptifibatide, and tirofiban, is pivotal in anti-platelet therapy. Pharmacodynamic studies on these three agents have revealed their capabilities of establishing and maintaining a $>80 \%$ inhibition of platelet aggregation [1].

The first GP IIb/IIIa receptor antagonist used in clinical settings is abciximab. This drug is the fragment of recombinant human-mouse chimeric monoclonal antibody, which can inhibit GP IIb/IIIa receptors in a dosedependent manner. Abciximab also inhibits $\alpha \operatorname{IIb} / \beta 3$ receptors (for vWF) on platelets, thereby inhibiting platelet aggregation via fibrinogen. However, abciximab have the disadvantages of potential immunogenicity, drug effect irreversibility, and high cost [2]. Hence, micromolecular GP IIb/IIIa receptor antagonists (e.g., eptifibatide and tirofiban) have been developed. These 


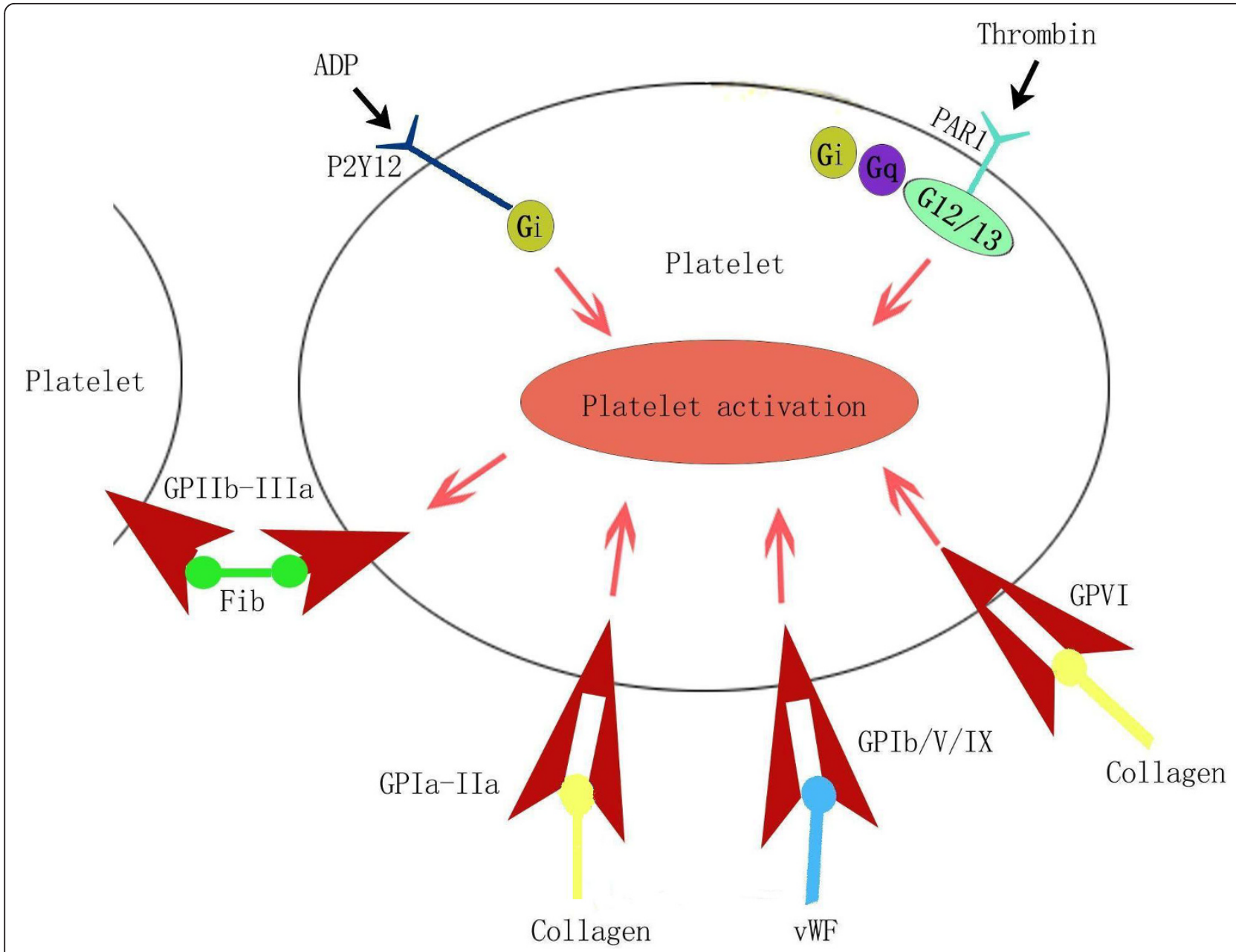

Figure 1 Different targets for anti-platelet therapy. According to the different targets, novel anti-platelet agents with different mechanism of action can be developed, including GP Ilb/llla antagonists, P2Y(12) receptor antagonists and Protease-activated receptor antagonists, etc.

micromolecular GP IIb/IIIa receptor antagonists contain the Arg-Gly-Asp (RGD) sequence. In the RGD sequence of eptifibatide, an arginine residue is replaced by the lysine residue. On the other hand, tirofiban is the micromolecular GP IIb/IIIa receptor antagonist synthesized according to the RGD module. These micromolecular agents, unlike abciximab, specifically act on GP IIb/IIIa receptors and do not combine with any other integrin. Eptifibatide and tirofiban also cannot induce immune response given their small molecular weights and low affinities to GP IIb/IIIa receptors.
Abciximab, eptifibatide, and tirofiban are all intravenously injected. Large-scale clinical trials have demonstrated the clear clinical effects and safety of these drugs in decreasing the ischemic events in acute coronary syndrome (ACS). Their uses in adjunctive therapy during percutaneous coronary intervention (PCI) have also been revealed $[3,4]$. However, adverse events related to thrombosis or bleeding have still been reported in cases of therapy with GP IIb/IIIa [5]. Trials on orally administered GP IIb/IIIa antagonists have failed to demonstrate any benefit, and even indicated significantly increased

Table 1 Glycoprotein Ilb/IIla antagonists

\begin{tabular}{|c|c|c|c|c|}
\hline Agents & Mechanism of action & Administration & Main side effects & State \\
\hline Abciximab & inhibit GPIlb/IIla receptor and GP $\alpha \| \mathrm{lb} / \beta 3$ receptor & IV & $\begin{array}{l}\text { allergy, bleeding, } \\
\text { thrombocytopenia }\end{array}$ & Approved \\
\hline Eptifibatide & inhibit GPIIb/Illa receptor & IV & $\begin{array}{l}\text { bleeding, } \\
\text { thrombocytopenia }\end{array}$ & Approved \\
\hline Tirofiban & inhibit GP IIb/IIla receptor & IV & $\begin{array}{l}\text { bleeding, } \\
\text { thrombocytopenia }\end{array}$ & approved \\
\hline
\end{tabular}


mortality in ACS cases [6]. Therefore, the development of GP IIb/IIIa antagonists needs further functional testing methods to assess the anti-platelet efficacy of these drugs in actual patients.

\section{Agents that selectively increase cyclic adenosine 3'-5'-monophosphate (CAMP) in platelets}

Platelet aggregation can be inhibited either by the blocking of membrane receptors or interaction with intracellular signaling pathways. cAMP and cyclic guanosine 3'5-monophosphate (cGMP) are two important intracellular second messengers for platelet function. Phosphodiesterase (PDE), which is obtained by catalyzing the hydrolysis of cAMP and cGMP, limits the intracellular levels of cyclic nucleotides to regulate platelet function. Therefore, the inhibition of PDEs may confer a strong inhibitory effect on platelets.

Cilostazol is an anti-platelet agent used in the treatment of peripheral ischemia, such as intermittent claudication. This drug is a kind of selective inhibitor of cAMP-PDE that can dilate blood vessels and hinder platelet aggregation induced by adenosine diphosphate (ADP), collagens and arachidonic acid. Unlike aspirin, cilostazol is a reversible platelet inhibitor that prevents both primary and secondary aggregation. In terms of pharmacokinetics, cilostazol is metabolized in the liver and excreted by the kidney.

Overall, cilostazol is a good drug of choice given its high tolerance, small number of side effects, high safety, and potential use with other anti-platelet drugs [7-9]. Cilostazol may also be a more safer and effective alternative to aspirin in the patients with ischemic stroke [10]. Presently, there is a trend towards enhanced anti-platelet effects when cilostazol is added to aspirin in the ischemic stroke patients. A combination of aspirin and cilostazol may be a good treatment option for these patients [11,12].

\section{P2Y(12) receptor antagonists(Table 2)}

P2Y(12) receptor antagonists are anti-thrombotic agents that inhibit platelet function by blocking the ADP at $\mathrm{P} 2 \mathrm{Y}(12)$ receptor sites. Adenine nucleotides act on platelets via three distinct P2 receptors, namely, two G protein-coupled ADP receptors, P2Y(1) and P2Y(12), as well as a P2X(1) receptor ligand-gated cation channel activated by adenosine triphosphate (ATP). The P2Y(1) receptor initiates platelet aggregation, but is not sufficient in response to ADP. On the other hand, the P2Y (12) receptor is responsible for the completion of aggregation in response to ADP. The P2Y(12) receptor is the molecular target of anti-thrombotic drugs such as clopidogrel, prasugrel, cangrelor, and ticagrelor. This receptor is responsible for most of the potentiating effects of ADP when platelets are activated by agonists such as collagen, thrombin $[13,14]$. These platelet antagonists blocking the ADP-receptor P2Y(12) decrease myocardial infarction, stroke, thrombosis and mortality in the patients with cardiovascular diseases. The P2Y(12) antagonists (e.g., clopidogrel, prasugrel, and ticagrelor) are now being used in clinical settings given their more protective effects [15].

Presently, the P2Y(12) receptor antagonists being developed are clopidogrel and prasugrel, which are thienopyridines, as well as cangrelor and ticagrelor, which are nonthienopyridines. Hence, these antagonists are potential anti-thrombotic drugs.

Clopidogrel is a thienopyridine with proven antithrombotic efficacy. However, it has the disadvantages of high inter-individual variability in pharmacological response, delayed onset and offset of action, as well as requiring to be metabolized to its active metabolite form [16].

Prasugrel has received its priority right of approval in 2008. It is a new kind of thienopyridine P2Y12 receptor antagonist that works by blocking the P2Y12 ADP receptor on the surfaces of platelets. Nevertheless, the clinical benefits of prasugrel are countered by increased bleeding risk compared with the conventional thienopyridine treatment using clopidogrel. In the clinical trial of prasugrel versus clopidogrel in patients with acute coronary syndromes (ClinicalTrials.gov number, NCT00097591), the rates of myocardial infarction in the prasugrel group were significantly reduced $(9.7 \%$ for clopidogrel vs. $7.4 \%$ for prasugrel; $\mathrm{P}<0.001$ ). There were also significant reductions in the urgent target-vessel revascularization $(3.7 \%$ vs. $2.5 \%$; $\mathrm{P}<0.001)$, and stent thrombosis $(2.4 \%$ vs. $1.1 \%$; $\mathrm{P}<0.001)$. However, there

Table 2 P2Y(12) receptor antagonists

\begin{tabular}{|c|c|c|c|c|}
\hline Agents & Mechanism of action & Administration & Main Side effects & State \\
\hline Clopidogrel & thienopyridine, blocking the effects of ADP at P2Y(12) receptor sites & Oral & $\begin{array}{c}\text { bleeding, } \\
\text { thrombocytopenia }\end{array}$ & approved \\
\hline Prasugrel & thienopyridine, blocking the effects of ADP at P2Y(12) receptor sites & Oral & bleeding & approved \\
\hline Cangrelor & $\begin{array}{l}\text { nonthienopyridine, the blocking effects of ADP at P2Y(12) receptor } \\
\text { sites }\end{array}$ & IV & bleeding & unapproved \\
\hline Ticagrelor & $\begin{array}{l}\text { nonthienopyridine, the blocking effects of ADP at P2Y(12) receptor } \\
\text { sites }\end{array}$ & Oral & bleeding & approved \\
\hline
\end{tabular}

Abbreviations: IV: intravenous; ADP:adenosine diphosphate. 
was more significant major bleeding in patients receiving prasugrel $(2.4 \%)$ than in patients receiving clopidogrel $(1.8 \%)(\mathrm{P}=0.03)$. The prasugrel group also had greater rate of life-threatening bleeding $(1.4 \%$ vs. $0.9 \%$; $\mathrm{P}$ $=0.01)$, including nonfatal bleeding $(1.1 \%$ vs. $0.9 \% ; \mathrm{P}=$ 0.23 ) and fatal bleeding (0.4\% vs. $0.1 \% ; \mathrm{P}=0.002)[17]$.

Still, some current practice guidelines incorporate prasugrel as a treatment option because it has a faster onset of action and more uniform inhibition of platelet function than clopidogrel. However, prasugrel is not presently recommended to be selected over clopidogrel in any patient subgroup. Further studies are required to determine the optimal dosage and patient characteristics for prasugrel treatments [18].

Two direct and reversible P2Y(12) antagonists, cangrelor and ticagrelor, are characterized by rapid onsets and reversibilities of platelet inhibition.

Similar with the nonthienopyridine P2Y(12) receptor antagonist, cangrelor is a reversible anti-platelet intravenous preparation with a rapid effect because it can function without needing to be metabolized. In a study of PCI patients, the use of cangrelor has shown no significant difference compared with abciximab in major adverse cardiac events and bleeding complications. Cangrelor is only intravenously administrated. However, there is no evidence that can prove its superiority over current commonly used intravenous anti-platelet agents (e.g., GP IIb/IIIa receptor antagonists such as abciximab) in preventing thrombotic events in patients undergoing PCI. Indeed, its therapeutic potential is uncertain [19].

On the other hand, ticagrelor is better than clopidogrel in preventing major adverse cardiac events in ACS patients. Compared with clopidogrel, ticagrelor decreases the incidences of major adverse cardiac events and thrombosis. Similar with prasugrel, ticagrelor is associated with high frequencies of bleeding complications. A short period of drug discontinuation before surgery is generally necessary in the ticagrelor-treated patients in order to limit the risk of post-surgical bleeding [20-23].

\section{Protease-activated receptor (PAR) antagonists (Table 3)}

PARs include PARA1, PARA2, PARA3, and PARA4. Similar with thrombin receptors, PAR1, PAR3, and PAR4 mediate platelet activation induced by thrombin.
In humans, only PAR1 and PAR4 are expressed. The ADP and thromboxane A2 (TXA2) platelet activation pathways exist during the progress of pathological thrombosis and physiological hemostasis. The combined use of aspirin and clopidogrel well inhibits thrombosis in induced hemorrhagic complications. PAR1-mediated platelet activation mainly promotes pathological thrombosis and has less influence on protective hemostasis. Hence, PAR1 antagonists decrease the incidence of hemorrhagic complications $[24,25]$. Oral PAR1 antagonists currently being researched include vorapaxar $(\mathrm{SCH}$ 530348) and atopaxar (E-5555).

Vorapaxar, a synthetic tricyclic 3-phenylpyridine, is a new orally active fourth generation himbacine-based antagonist of the protease-activated receptor PAR1, and is the primary receptor for thrombin in human platelets. Vorapaxar is a non-peptide competitive PAR1 thrombin receptor antagonist with a high affinity and low molecular weight. It belongs to the first agent in a new type of compounds that inhibit thrombin-mediated platelet aggregation without affecting the enzymatic activity of thrombin on fibrinogen. Preclinical and initial clinical studies have demonstrated the high potential of vorapaxar in inhibiting thrombin-induced platelet activation, as well as its excellent oral bioavailability and safety [26]. Vorapaxar inhibits thrombin-mediated platelet aggregation mediated, and does not influence hemostasis as well as bleeding time. Hence, this drug potentially decreases the risk for ischemic events without significantly increasing the rate of bleeding. Vorapaxar, which is orally administered, is rapidly absorbed and has a long biological half-life $[27,28]$.

Atopaxar is another powerful oral PAR1 antagonist. Preclinical studies have indicated that atopaxar inhibits thrombin-mediated platelet aggregation mediated without increasing the rate of bleeding. The selective blocking of platelet receptors by atopaxar suggests its therapeutic potential in thrombotic disease [29-31].

\section{Novel anti-platelet drugs}

The interaction between platelets and collagen is the motivator of platelet adhesion, aggregation, and activation. This interaction has become the target for developing new anti-platelet agents. On the surfaces of platelets, there exist at least three kinds of receptors that can combine with collagen, including GP Ib/IX (functions

Table 3 Protease-activated receptor (PAR) antagonists

\begin{tabular}{|c|c|c|c|c|}
\hline Agents & Mechanism of action & Administration & $\begin{array}{l}\text { Main side } \\
\text { effects }\end{array}$ & State \\
\hline Vorapaxar & $\begin{array}{l}\text { a non-peptide competitivePAR1 thrombin receptor antagonist with a high affinity and } \\
\text { low molecular weight }\end{array}$ & oral & bleeding & unapproved \\
\hline Atopaxar & PAR1 antagonist inhibiting thrombin-mediated platelet aggregation & oral & bleeding & unapproved \\
\hline
\end{tabular}

Abbreviations: PAR:protease-activated receptor. 
with the vWF), GP Ia-IIa (the main receptor in platelet adhesion), and GPVI (mediates platelet activation). Platelets adhesion to the damaged blood vessel is the initial trigger for arterial hemostasis and thrombosis. Platelets adhere to the sub-endothelium via their interaction with the vWF, which forms a bridge between collagens within the damaged vessel wall [32-34]. The development of monoclonal antibodies that inhibit platelet adhesion or aggregation targets collagen-vWF-GPIb and collagenGPVI [35-37].

The 6B4-antigen-binding fragment (Fab) is a murine monoclonal antibody that targets the human platelet GPIb alpha (201-268aa) and blocks the binding of the vWF. It has been proved as a powerful anti-thrombotic agent without the side effects of bleeding or thrombocytopenia. The anti-thrombotic effects of 6B4-Fab on acute platelet-mediated thrombosis have been studied in baboons. Minimal effects on the bleeding time, absence of spontaneous bleeding, and absence of thrombocytopenia are observed. Hence, H6B4-Fab can be further developed [38]. There are some other promising preclinical agents targeting GP Ib. Such agents include GPG290 , a recombinant chimeric protein containing aminoterminal 290 amino acids of alpha linked to the human IgG1 crystallizable fragment, and Shuzhou2 (SZ2), an anti-GP Ib monoclonal antibody [39].

The vWF plays an important role in both hemostasis and thrombosis. Platelets adhere to damaged arteries by the interactions between the vWF A1-domain and glycoprotein Ib receptors under conditions of high shear. This initial platelet binding event stimulates platelet activation, recruitment, and activation of the clotting cascade, thereby promoting thrombus formation. Therefore, the monoclonal antibody against the functional domains (A1 and A3) of the vWF can effectively inhibit thrombosis. The genetically engineered antibody AJW200 is a humanized anti-vWF-A1 chimeric Fab antibody that can block the combination of the vWF and GP Ib. Consequently, platelet adhesion and aggregation are inhibited without remarkably prolonging the bleeding time. The recombinant chimeric monoclonal antibody 82D6A3 against the vWF-A3 region can block the combination of the A3 region and collagen to inhibit platelet adhesion. ARC1779, which has a high binding affinity with the vWF A1-domain, has been proven to inhibit botrocetin-induced and shear force-induced platelet aggregation. Besides, ARC15105 is a chemically advanced follower with a potential higher affinity to the vWF [40,41].

GPVI, which is a major receptor of collagen on platelet surfaces, mediates the initial platelet contacting with collagen, which can cause platelet adhesion, aggregation, and thrombosis $[42,43]$. GPVI may be considered as an interesting and prospective target in the development of anti-platelet agents [44-46]. Anti-GPVI antibodies, such as the monoclonal antibody JAQ1, can significantly prevent thrombosis with a little prolonged bleeding time [47].

\section{Conclusions and future directions}

Given the increasing incidence of and mortality from thrombotic diseases, anti-platelet agents have been extensively researched and developed $[48,49]$. The combined use of anti-platelet drugs with different mechanisms may be important in anti-thrombotic treatments. Further research on platelet functions may give rise to numerous new anti-platelet agents. Pharmacodynamic platelet function assays and pharmacokinetic tests for individualizing and optimizing anti-platelet therapy may find their way into clinical use. However, more studies are needed. Hopefully, new selective platelet inhibitors with high anti-thrombotic efficiencies and low adverse hemorrhagic side affects can be developed.

\section{List of abbreviations used}

GP: glycoprotein; vWF: von Willebrand factor; PCl: percutaneous coronary intervention; ACS: acute coronary syndrome; RGD: Arg-Gly-Asp; ADP: adenosine diphosphate; ATP: adenosine triphosphate; CAMP: cyclic adenosine 3'-5'-monophosphate; cGMP: cyclic guanosine 3'-5monophosphate; PDE: phosphodiesterase; PAR: protease-activated receptor; TXA2: thromboxane A2; Fab: antigen-binding fragment; SZ2: shuzhou2

\section{Acknowledgements}

The present study was partially supported by the National Natural Science Foundation (81100336, 81070396, 81070411, 81070408, and 30971278), the Natural Science Foundation of Shandong Province (ZR2010CQ040), the Research Fund for the Doctoral Program of Higher Education of China (20100131120058), and the Doctor Foundation of Shandong Province (2008BS03009). Cultivation Fund of the Key Scientific and Technical Innovation Project, Ministry of Education of China (NO704030), Taishan Scholar Fundation, and the SRF for ROCS, SEM.

\section{Authors' contributions}

The present manuscript was drafted by XJ and revised by MH. All authors read and approved the final manuscript.

\section{Competing interests}

The authors declare that they have no competing interests.

Received: 22 August 2011 Accepted: 4 November 2011 Published: 4 November 2011

\section{References}

1. Proimos G: Platelet aggregation inhibition with glycoprotein llb-Illa inhibitors. J Thromb Thrombolysis 2001, 11:99-110.

2. Vergara-Jimenez J, Tricoci P: Safety and efficacy of abciximab as an adjunct to percutaneous coronary intervention. Vasc Health Risk Manag 2010, 6:39-45.

3. Gross PL, Weitz J: New antithrombotic drugs. Clin Pharmacol Ther 2009, 86:139-146.

4. Lippi G, Montagnana M, Danese E, Favaloro EJ, Franchini M: Glycoprotein Illb/llla inhibitors: an update on the mechanism of action and use of functional testing methods to assess anti-platelet efficacy. Biomark Med 2011, 5:63-70.

5. Winchester DE, Wen X, Brearley WD, Park KE, Anderson RD, Bavry AA: Efficacy and safety of glycoprotein Ilb/lla inhibitors during elective coronary revascularization: a meta-analysis of randomized trials 
performed in the era of stents and thienopyridines. J Am Coll Cardiol 2011, 57:1190-1199.

6. Chew DP, Bhatt DL, Sapp S, Topol EJ: Increased mortality with oral platelet glycoprotein IIb/IIla antagonists: A metanalysis of phase III multicenter randomized trials. Circulation 2001, 103:201-206.

7. Shinohara Y, Katayama Y, Uchiyama S, Yamaguchi T, Handa S, Matsuoka K, Ohashi Y, Tanahashi N, Yamamoto H, Genka C, Kitagawa Y, Kusuoka H, Nishimaru K, Tsushima M, Koretsune Y, Sawada T, Hamada C, CSPS 2 group: Cilostazol for prevention of secondary stroke (CSPS2): an aspirincontrolled, double-blind, randomised non-inferiority trial. Lancet Neurol 2010, 9:959-968.

8. Jeong YH, Hwang JY, Kim IS, Park Y, Hwang SJ, Lee SW, Kwak CH, Park SW: Adding cilostazol to dual anti-platelet therapy achieves greater platelet inhibition than high maintenance dose clopidogrel in patients with acute myocardial infarction: Results of the adjunctive cilostazol versus high maintenance dose clopidogrel in patients with AMI (ACCEL-AMI) study. Circ Cardiovasc Interv 2010, 3:17-26.

9. Kim JY, Lee K, Shin M, Ahn M, Choe H, Yoo BS, Yoon J, Choe KH, Lee SH: Cilostazol could ameliorate platelet responsiveness to clopidogrel in patients undergoing primary percutaneous coronary intervention. Lancet Neurol 2008, 7:494-499

10. Huang Y, Cheng Y, Wu J, Li Y, Xu E, Hong Z, Li Z, Zhang W, Ding M, Gao X, Fan D, Zeng J, Wong K, Lu C, Xiao J, Yao C, Cilostazol versus Aspirin for Secondary Ischaemic Stroke Prevention cooperation investigators: Cilostazol as an alternative to aspirin after ischaemic stroke: a randomised, double-blind, pilot study. Lancet Neurol 2008, 7:494-499.

11. Lee JH, Cha JK, Lee SJ, Ha SW, Kwon SU: Addition of cilostazol reduces biological aspirin resistance in aspirin users with ischaemic stroke: a double-blind randomized clinical trial. Eur I Neurol 2010, 17:434-442.

12. Cleanthis M, Bhattacharya V, Smout J, Ashour H, Stansby G: Combined aspirin and cilostazol treatment is associated with reduced platelet aggregation and prevention of exercise-induced platelet activation. Eur $\rfloor$ Vasc Endovasc Surg 2009, 37:604-610.

13. Hechler B, Cattaneo M, Gachet C: The P2 receptors in platelet function. Semin Thromb Hemost 2005, 31:150-161.

14. Iyú D, Glenn JR, White AE, Fox SC, van Giezen H, Nylander S, Heptinstall S: Mode of action of $\mathrm{P} 2 \mathrm{Y}(12)$ antagonists as inhibitors of platelet function. Thromb Haemost 2011, 105:96-106.

15. Erlinge D: P2Y receptors in health and disease. Adv Pharmacol 2011, 61:417-439.

16. Cattaneo M, Podda GM: State of the art of new P2Y12 antagonists. Intern Emerg Med 2010, 5:385-391.

17. Wiviott SD, Braunwald E, McCabe CH, Montalescot G, Ruzyllo W, Gottlieb S, Neumann FJ, Ardissino D, De Servi S, Murphy SA, Riesmeyer J, Weerakkody G, Gibson CM, Antman EM, TRITON-TIMI 38 Investigators: Prasugrel versus clopidogrel in patients with acute coronary syndromes. N Engl J Med 2007, 357:2001-2015.

18. Mousa SA, Jeske WP, Fareed J: Prasugrel: a novel platelet ADP P2Y(12) receptor antagonist. Methods Mol Biol 2010, 663:221-228.

19. Ueno M, Ferreiro JL, Angiolillo DJ: Update on the clinical development of cangrelor. Expert Rev Cardiovasc Ther 2010, 8:1069-1077.

20. Bliden KP, Tantry US, Storey RF, Jeong YH, Gesheff M, Wei C, Gurbel PA: The effect of ticagrelor versus clopidogrel on high on-treatment platelet reactivity: Combined analysis of the ONSET/OFFSET and RESPOND studies. Am Heart J 2011, 162:160-165.

21. Mahaffey KW, Wojdyla DM, Carroll K, Becker RC, Storey RF, Angiolillo DJ, Held C, Cannon CP, James S, Pieper KS, Horrow J, Harrington RA, Wallentin L, on behalf of the PLATO Investigators: Ticagrelor Compared With Clopidogrel by Geographic Region in the Platelet Inhibition and Patient Outcomes (PLATO) Trial. Circulation 2011, 124:544-554.

22. James S, Budaj A, Aylward P, Buck KK, Cannon CP, Cornel JH, Harrington RA, Horrow J, Katus H, Keltai M, Lewis BS, Parikh K, Storey RF, Szummer K, Wojdyla D, Wallentin L: Ticagrelor versus clopidogrel in acute coronary syndromes in relation to renal function: results from the Platelet Inhibition and Patient Outcomes (PLATO) trial. Circulation 2010, 122:1056-1067

23. Wallentin L, Becker RC, Budaj A, Cannon CP, Emanuelsson H, Held C, Horrow J, Husted S, James S, Katus H, Mahaffey KW, Scirica BM, Skene A Steg PG, Storey RF, Harrington RA, PLATO Investigators, Freij A, Thorsén M: Ticagrelor versus clopidogrel in patients with acute coronary syndromes. N Engl J Med 2009, 361:1045-1057.
24. White HD: Oral anti-platelet therapy for atherothrombotic disease: current evidence and new directions. Am Heart J 2011, 161:450-461.

25. Chintala M, Shimizu K, Ogawa M, Yamaguchi H, Doi M, Jensen P: Basic and translational research on proteinase-activated receptors: antagonism of the proteinase-activated receptor 1 for thrombin, a novel approach to anti-platelet therapy for atherothrombotic disease. J Pharmacol Sci 2008, 108:433-438.

26. Bonaca MP, Morrow DA: SCH 530348: a novel oral thrombin receptor antagonist. Future Cardiol 2009, 5:435-442

27. Hildemann SK, Bode C: Improving anti-platelet therapy for atherothrombotic disease: preclinical results with $\mathrm{SCH} 530348$, the first oral thrombin receptor antagonist selective for PAR-1. Hamostaseologie 2009, 29:349-355.

28. Oestreich J: SCH-530348, a thrombin receptor (PAR-1) antagonist for the prevention and treatment of atherothrombosis. Curr Opin Investig Drugs 2009, 10:988-996.

29. Kogushi M, Matsuoka T, Kawata T, Kuramochi H, Kawaguchi S, Murakami K, Hiyoshi H, Suzuki S, Kawahara T, Kajiwara A, Hishinuma I: The novel and orally active thrombin receptor antagonist E5555 (Atopaxar) inhibits arterial thrombosis without affecting bleeding time in guinea pigs. Eur J Pharmacol 2011, 657:131-137.

30. Kogushi M, Matsuoka T, Kuramochi H, Murakami K, Kawata T, Kimura A, Chiba K, Musha T, Suzuki S, Kawahara T, Kajiwara A, Hishinuma I: Oral administration of the thrombin receptor antagonist E5555 (atopaxar) attenuates intimal thickening following balloon injury in rats. Eur J Pharmacol 2011, 666:158-164

31. Serebruany VL, Kogushi M, Dastros-Pitei D, Flather M, Bhatt DL: The in-vitro effects of E5555, a protease-activated receptor (PAR)-1 antagonist, on platelet biomarkers in healthy volunteers and patients with coronary artery disease. Thromb Haemost 2009, 102:111-119.

32. Vanhoorelbeke K, Ulrichts H, Schoolmeester A, Deckmyn H: Inhibition of platelet adhesion to collagen as a new target for antithrombotic drugs. Curr Drug Targets Cardiovasc Haematol Disord 2003, 3:125-140.

33. Naimushin YA, Mazurov AV: Von Willebrand factor can support platelet aggregation via interaction with activated GPIIlb-llla and GPIb. Platelets 2004, 15:419-425.

34. Sivaraman B, Latour RA: Delineating the roles of the GPIII/IIla and GP-IbIX-V platelet receptors in mediating platelet adhesion to adsorbed fibrinogen and albumin. Biomaterials 2011, 32:5365-5370

35. Best $D$, Senis $Y A$, Jarvis GE, Eagleton HJ, Roberts DJ, Saito T, Jung SM, Moroi M, Harrison P, Green FR, Watson SP: GPVI levels in platelets: relationship to platelet function at high shear. Blood 2003, 102:2811-2818.

36. Nieswandt B, Watson SP: Platelet-collagen interaction: is GPVI the central receptor? Blood 2003, 102:449-461.

37. De Meyer SF, Vanhoorelbeke K, Ulrichts H, Staelens S, Feys HB, Salles Fontayne A, Deckmyn H: Development of monoclonal antibodies that inhibit platelet adhesion or aggregation as potential anti-thrombotic drugs. Cardiovasc Hematol Disord Drug Targets 2006, 6:191-207.

38. Fontayne $\mathrm{A}$, Meiring $\mathrm{M}$, Lamprecht $\mathrm{S}$, Roodt J, Demarsin E, Barbeaux $\mathrm{P}$ Deckmyn H: The humanized anti-glycoprotein lb monoclonal antibody h6B4-Fab is a potent and safe antithrombotic in a high shear arterial thrombosis model in baboons. Thromb Haemost 2008, 100:670-677.

39. Cauwenberghs N, Meiring M, Vauterin S, van Wyk V, Lamprecht S, Roodt JP, Novák L, Harsfalvi J, Deckmyn H, Kotzé HF: Antithrombotic effect of platelet glycoprotein Ib-blocking monoclonal antibody Fab fragments in nonhuman primates. Arterioscler Thromb Vasc Biol 2000, 20:1347-1353.

40. Diener JL, Daniel Lagassé HA, Duerschmied D, Merhi Y, Tanguay JF, Hutabarat R, Gilbert J, Wagner DD, Schaub R: Inhibition of von Willebrand factor-mediated platelet activation and thrombosis by the anti-von Willebrand factor A1-domain aptamer ARC1779. Thromb Haemost 2009, 7:1155-1162.

41. Firbas C, Siller-Matula JM, Jilma B: Targeting von Willebrand factor and platelet glycoprotein Ib receptor. Expert Rev Cardiovasc Ther 2010, 8:1689-1701.

42. Sarratt KL, Chen H, Zutter MM, Santoro SA, Hammer DA, Kahn ML: GPVI and alpha2beta1 play independent critical roles during platelet adhesion and aggregate for mation to collagen under flow. Blood 2005, 106:1268-1277.

43. Moog S, Mangin P, Lenain N, Strassel C, Ravanat C, Schuhler S, Freund M, Santer M, Kahn M, Nieswandt B, Gachet C, Cazenave JP, Lanza F: Platelet 
glycoprotein $\mathrm{V}$ binds to collagen and participates in platelet adhesion and aggregation. Blood 2001, 98:1038-1046.

44. Li H, Lockyer S, Concepcion A, Gong X, Takizawa H, Guertin M,

Matsumoto Y, Kambayashi J, Tandon NN, Liu Y: The Fab fragment of a

novel anti-GPVI monoclonal antibody, OM4, reduces In Vivo thrombosis without bleeding risk in rats. Arterioscler Thromb Vasc Biol 2007,

27:1199-1205

45. Qian MD, Villeval JL, Xiong X, Jandrot-Perrus M, Nagashima K, Tonra J, McDonald K, Goodearl A, Gill D: Anti GPVI human antibodies neutralizing collagen induced platelet aggregation isolated from a combinatorial phage display library. Hum Antibodies 2002, 11:97-105.

46. Smethurst PA, Joutsi-Korhonen L, O'Connor MN, Wilson E, Jennings NS, Garner SF, Zhang Y, Knight CG, Dafforn TR, Buckle A, IJsseldijk MJ, De Groot PG, Watkins NA, Farndale RW, Ouwehand WH: Identification of the primary collagen binding surface on human glycoprotein by site directed mutagenesis and by a blocking phage antibody. Blood 2004 103:903-911

47. Grüner S, Prostredna M, Aktas B, Moers A, Schulte V, Krieg T, Offermanns S, Eckes B, Nieswandt B: Anti-glycoprotein VI treatment severely compromises hemostasis in mice with reduced alpha2beta1 levels or concomitant aspirin therapy. Circulation 2004, 110:2946-2951.

48. Robert F: The potential benefits of low-molecular-weight heparins in cancer patients. J Hematol Oncol 2010, 3:3.

49. Budhu A, Ji J, Wang XW: The clinical potential of microRNAs. J Hematol Oncol 2010, 3:37.

doi:10.1186/1756-8722-4-44

Cite this article as: $\mathrm{Ji}$ and Hou: Novel agents for anti-platelet therapy. Journal of Hematology \& Oncology 2011 4:44.

\section{Submit your next manuscript to BioMed Central and take full advantage of:}

- Convenient online submission

- Thorough peer review

- No space constraints or color figure charges

- Immediate publication on acceptance

- Inclusion in PubMed, CAS, Scopus and Google Scholar

- Research which is freely available for redistribution

Submit your manuscript at www.biomedcentral.com/submit 